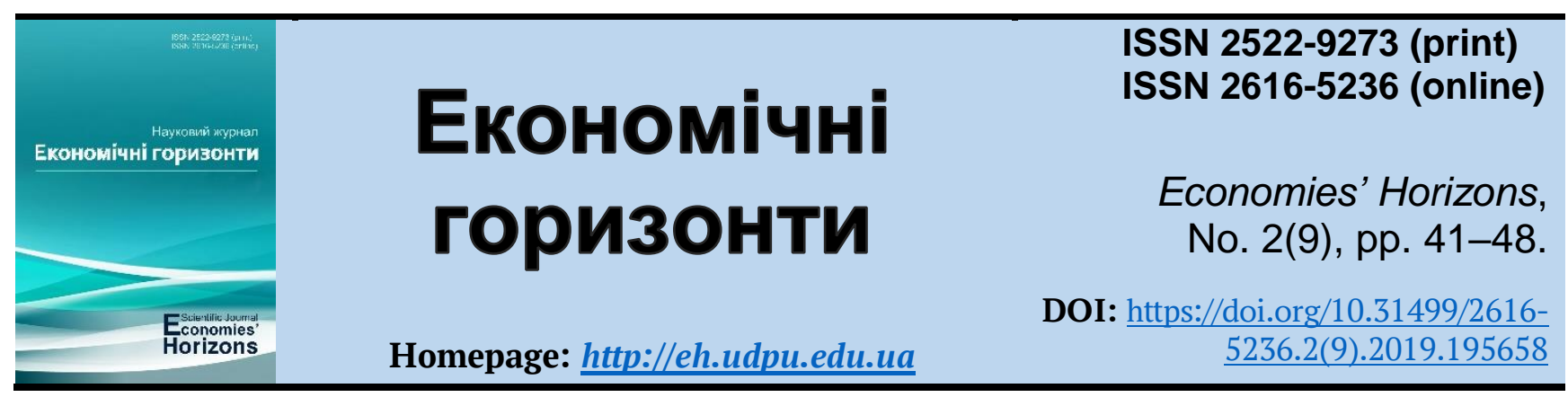

UDC 364.3(477)-058.862

\title{
Social support for orphans and children deprived of parental care: Ukrainian innovations
}

\author{
Iryna V. Albul ${ }^{1}$, Cand. Ped. Sc., Associate Professor
}

Received: 20 April 2019

Accepted: 24 May 2019

Albul, I. V. (2019), "Social support for orphans and children deprived of parental care: Ukrainian innovations", Economies' Horizons, no. 2(9), pp. 41-48, doi: https://doi.org/10.31499/2616-5236.2(9).2019.195658.

\begin{abstract}
Modern European integration of Ukraine provides for the revision of the main guidelines in the state policy for creating conditions for satisfying the needs and interests of children, and realization of their rights. In particular, the main factor in the field of childhood protection is the focus on the upbringing of the child in the family environment, in support of the family; as an alternative, in the absence of parental care, to create a child-friendly environment. This orientation requires changes in the social support of orphans and children deprived of parental care. The purpose of the research. The aim of the study is to highlight and analyze certain aspects of Ukraine's innovation activities regarding social support for orphans and children deprived of parental care; determine innovative features of social protection of Ukrainian children in terms of parental care absence. Methodology. The use of methods of analysis, synthesis and generalization revealed the main tendencies of innovative activity of the state authorities regarding orphans and children deprived of parental care. Results and practical meaning. It has been found out that the innovative development of the Ukrainian social support system for orphans and children deprived of parental care is due to positive world experience and focused on the protection of the best interests of the child and the satisfaction of their vital needs; reforming social protection system requires active involvement of the state and civil society institutions, aimed at the deinstitutionalization of placement of orphans and children deprived of parental care, and reorientation of the principles of financial support for families with adopted children; special attention is paid to cooperation with business representatives and international donors. The following basic vectors of social support for orphans and children deprived of parental care have been stated: modernization of algorithms for financing establishments of institutional type, approval of co-financing mechanisms from state and local budgets, and approval of state standards for social care for families with specified category of children. Prospects for further research. The study and analysis of regional programs of social support for orphans and children deprived of parental care in terms of decentralization and funding have been identified as promising.
\end{abstract}

Keywords: orphans and children deprived of parental care; social support; innovative activity.

JEL Classification: H53, H55, I38, J13, O35.

Number of references: 12; number of tables: 0; number of figures: 0; number of formulas: $\mathbf{0 .}$

\footnotetext{
${ }^{1}$ Pavlo Tychyna Uman State Pedagogical University; Head of the Department of Social Pedagogy and Social Work; ORCID ID: http://orcid.org/0000-0001-7056-3157; e-mail: alirvol@i.ua.
} 


\title{
Соціальне забезпечення дітей-сиріт та дітей, позбавлених батьківського піклування: українські інновації
}

\author{
Ірина Володимирівна Албул ${ }^{1}$, к. пед. н., доцент
}

\author{
Стаття надійшла: 20.04.2019 \\ Стаття прийнята: 24.05.2019
}

Albul I. V. Social support for orphans and children deprived of parental care: Ukrainian innovations. Економічні горизонти. 2019. № 2(9). C. 41-48. DOI: 10.31499/2616-5236.2(9).2019.195658.

Анотація. Сучасна євроінтеграція України передбачає перегляд основних орієнтирів у державній політиці щодо створення умов для задоволення потреб та інтересів дітей, реалізації їх прав. Зокрема, основним вектором у сфері охорони дитинства вбачається спрямованість на виховання дитини у родинному оточенні, на підтримку сім'ї; як альтернатива в разі відсутності батьківського піклування - на створення середовища розвитку дитини, максимально наближеного до сімейного. Така спрямованість вимагає змін у соціальному забезпеченні дітейсиріт та дітей, позбавлених батьківського піклування. Мета дослідження полягає у висвітленні та аналізі окремих аспектів інноваційної діяльності України щодо соціального забезпечення дітей-сиріт та дітей, позбавлених батьківського піклування; виокремленні інноваційних ознак соціального захисту українських дітей в умовах відсутності батьківської опіки. Методологія. Завдяки використанню методів аналізу, синтезу та узагальнення виявлено основні тенденції інноваційної діяльності державних органів влади щодо дітей-сиріт та дітей, позбавлених батьківського піклування. Результати і практичне значення. 3'ясовано, що інноваційний розвиток української системи соціального забезпечення дітей-сиріт та дітей, позбавлених батьківського піклування, зумовлений позитивним світовим досвідом та зорієнтований на захист найкращих інтересів дитини і задоволення життєво важливих потреб; Виявлено, що реформування системи соціального захисту вимагає активної взаємодії зусиль держави й інститутів громадянського суспільства, спрямоване на деінституталізацію влаштування дітейсиріт та дітей, позбавлених батьківського піклування, й переорієнтування принципів грошового забезпечення сімей 3 прийомними дітьми; окремої уваги приділяється співпраці 3 представниками бізнесових кіл та міжнародними донорами. Встановлено основні вектори соціального забезпечення дітей-сиріт та дітей, позбавлених батьківського піклування: модернізація алгоритмів фінансування закладів інституційного типу, затвердження механізмів співфінансування 3 державних і місцевих бюджетів та затвердження державних стандартів соціального обслуговування сімей 3 дітьми вказаної категорії. Перспективи подальших досліджень. Визначено перспективним вивчення та аналіз регіональних програм соціального забезпечення дітей-сиріт та дітей, позбавлених батьківського піклування, в умовах децентралізації влади і фінансування.

Ключові слова: діти-сироти та діти, позбавлені батьківського піклування; соціальне забезпечення; інноваційна діяльність.

Кількість джерел: 12; кількість таблиць: 0; кількість рисунків: 0; кількість формул: 0.

\section{Introduction.}

Modern European Integration of Ukraine provides for revision of state policy priorities in the field of childhood protection, implementation of successful approaches to the world practice of child support based on the protection of their rights and interests. It is also aimed at supporting the family, creating conditions for upbringing and developing children in the family or a family-friendly environment. At present, 70,491 children are registered as orphans and children deprived of parental

\footnotetext{
1 Уманський державний університет імені Павла Тичини; завідувач кафедри соціальної педагогіки та соціальної роботи; ідентифікатор ORCID: http://orcid.org/0000-0001-7056-3157; e-mail: alirvol@i.ua.
} 
care in Ukraine (22,126 orphans and 48,365 deprived of parental care). In family forms of education there are 64,709 children (guardianship - 50,766, foster families and orphanages - 13,943) (Ministry of Social Policy, 2018). Solving the problem of orphaned children and lack of parental care requires overall socioeconomic and demographic rehabilitation of Ukrainian society, the improvement of the economic situation, that is, social support of children of this category needs attention and reform. As a socioeconomic concept, "social support" is a relationship regarding the redistribution of national income in order to ensure the established social standards of living for each person in terms of social risks.

\section{Literature review.}

The novelty of the issue of social support for orphans and children deprived of parental care is confirmed by the steady attention of the scientific community. For example, O. Potopakhina (2008) was the first researcher in the field of social support law to comprehensively investigate the system of social protection measures for orphans and children deprived of parental care; the rights and guarantees of the specified category of children and persons in education and labour. The scientist interpreted the concept of social protection as a system of state-guaranteed economic, legal, organizational measures, for full state support in accordance with state social standards and obtaining the envisaged by law benefits to meet their essential needs and create conditions for normal life.

The research of M. Polyakova (2013) devoted to analysis of the state social and legal protection of orphans and children deprived of parental care in the aspect of their legal socialization. In particular, certain theoretical, organizational and legal principles of social protection of orphans and children deprived of parental care mechanism in Ukraine have been identified; proposals for improvement of national legislation in the social protection of orphans and children deprived of parental care and practices for its implementation have been made.
Such researchers as O. Pohribna, T. Shevchenko and A. Yevdokymova (2015) analyzed state policy and strategic orientations of social protection of orphans and children deprived of parental care in the context of reforming the state system of guardianship. The scientists also proposed hierarchy of administration in the sphere of social protection of these children.

The famous scientist O. Mordan (2015) in her thesis comprehensively and systematically examined state policies for the social protection of children without parental care. She treated this line of public policy as an organized and integrated system of activity of state authorities and local self-government aimed at improving the situation of orphans and children deprived of parental care and neglected children, aimed at restoring and exercising their rights to family care, support and full welfare, creating optimal conditions for improvement of life in society.

O. Prokopenko (2018) emphasized the problem of social orphanages and the need for taking measures to prevent that problem by carrying out preventive work among the population and ensuring the fulfilment of the obligations undertaken by the state to fully provide for orphans and children deprived of parental care.

Sharing the opinions of the mentioned researchers on the relevance of the orphanage problem and the need for an active position of the state in its solution, we consider it expedient to cover and analyze some aspects of innovative activity of Ukraine on social support for orphans and children deprived of parental care, which is the aim of this article.

\section{Methods.}

The research used the following theoretical methods of scientific knowledge: systematization - made it possible to generalize the results of scientific research on the topic of the article; analysis, synthesis and generalization to identify the main tendencies of innovative activity of state authorities in relation to orphans and children deprived of parental care. 
4. Research objectives: to highlight and analyze certain aspects of the state policy on social support for orphans and children deprived of parental care, to distinguish innovative features of social protection of children deprived of parental care.

\section{Results and discussions.}

According to the best international experience, governments and local governments provide the development of a sufficiently broad range of services for children and families with children.

The introduction of social, medical, educational, and rehabilitation services requires the necessary financial and human resources. Experience shows that the system of institutional care and upbringing of children is costly, does not ensure successful socialization of personality, impedes social adaptation at all stages of the child's development. The need to solve this problem requires an active reform of the institutional care system and upbringing of children. We emphasize the importance of uniting efforts of both the state and civil society with the support of representatives of business circles and international donors of Ukraine. The state's innovative orientation towards social support for orphans and children deprived of parental care was described in the state document "National strategy for reforming the institutional care and upbringing of children for 2017-2026 (hereinafter "Strategy")" (The Verkhovna Rada of Ukraine, 2017a).

The Strategy based on the following principles: the safety and well-being of the child is a priority of state policy; family is the best environment for upbringing and developing a child; preserving the family for a child is a key prerequisite for the best interests of the child and his or her well-being; responsible parenting is encouraged and supported by the state; the reform of the institutional care system and upbringing of children is carried out taking into account the needs, opinions and interests of each child; involving children in making decisions about their lives and future.
In order to integrate and coordinate actions to ensure the reform of the institutional care system and upbringing of children, efforts are being made by stakeholders to accomplish the following tasks:

- On the legal framework (improvement of legislation to ensure the reform of the institutional care and upbringing of children; integration of the main principles, goals and objectives of the Strategy into the priority areas of executive authorities activity).

- On coordinating the efforts of the entities implementing the Strategy (introducing an interagency coordination mechanism to achieve the goals and objectives of the Strategy; specifying and delineating the powers and responsibilities of executive authorities at central and local levels to ensure the rights of a child and support the family; powers of local self-government bodies, development and implementation of regional plans for reforming the institutional care system and upbringing of children).

- On financial support for the reforming process (development of financial mechanisms to support the reform of the institutional care system and upbringing of children, development of child support services and families with children).

- On monitoring and evaluation of the quality of the planned measures implementation (development and implementation of a system of monitoring and evaluation of the process of reforming the institutional care system and upbringing of children; introduction of a decision-making mechanism in the best interests of a child by all entities providing and protecting their rights, as well as involving children in decision-making on issues related to their lives).

The development of an effective and capable system of support for the growth of children in the family is conditioned by the suitability of the local community and the needs of its residents, and requires attention to be paid to the following aspects: support for the child's biological family, early identification of 
vulnerable families with children; development of the territorial network of social services; ensuring accessibility of services for children with special needs, in particular children with disabilities, and families with such children; support for families with children in difficult life circumstances in order to maintain a family for the child; involvement of non-governmental organizations in providing services to families with children; creating effective support mechanisms for families with children, combining financial assistance and services to help parents in fulfilling their child care and upbringing responsibilities and overcoming difficult life circumstances; providing the necessary level of professional competence for professionals giving services to children and families with children; developing and implementing mechanisms to monitor and evaluate the situation in territorial communities to ensure the realization of the right of a child to family upbringing (The Verkhovna Rada of Ukraine, 2017a).

Ensuring quality alternative care for children without parental care in order to prevent such children from entering institutional care establishments is possible under conditions of development of alternative care services for children who for some reason cannot live with their biological parents; providing alternative childcare services for children up to three years in order to stop the practice of referring such children to institutional care establishments; taking measures to stop the placement of children in institutions of care and upbringing of children for reasons of poverty or family in difficult circumstances; introduction of a mechanism for taking into account the interests and individual needs of each child in determining the form of their arrangement; developing and approving quality standards for alternative childcare services; development and approval of standard of service for preparation for independent life of children being brought up in alternative child care system (The Verkhovna Rada of Ukraine, 2017a).

According to the "Plan of Measures for the Implementation of Phase I of the National
Strategy for Reforming the Institutional Care System and Child Care System for 20172026", the main executive authorities are charged with implementing such measures as developing regulatory acts to modernize approaches to financing institutional care establishments, in particular on the introduction of a mechanism for co-financing from the state and local budgets measures for the creation of family-type orphanages to enhance the development of services on children care in the family directly in the local community at the place of a child's origin (The Verkhovna Rada of Ukraine, 2017b).

A separate measure is the approval of the minimum state social standard for the monthly maintenance of orphans and children deprived of parental care, in accordance with the Law of Ukraine "On Ensuring Organizational and Legal Conditions of Social Protection of Orphaned Children and Deprived of Parental Care" (The Verkhovna Rada of Ukraine, 2015).

In general, state social standards are social norms, established by laws or other normative legal acts, on the basis of which the levels of main state social guarantees are determined. The purpose of establishing state social standards and norms is to determine the mechanism of realization of social rights and state social guarantees of citizens, stipulated by the Constitution of Ukraine; determining the priorities of the state social policy for ensuring the human needs for material goods and services and financial resources for their realization; definition and justification of the amount of expenditures of budgetary and social funds for social protection and provision of population and maintenance of the social sphere. State social standards are necessarily taken into account when developing programs for economic and social development (The Verkhovna Rada of Ukraine, 2015).

For example, "The State Standard of Social Support for Families with Orphans and Children Deprived of Parental Care" defines the content, scope, conditions, and procedure for providing social support for families with 
orphans and children deprived of parental care (foster families, family-type orphanages), indicators of its quality for the entities of all forms of ownership and management providing this service. This document applies to the organization and implementation of social support for families bringing up orphans and children deprived of parental care, as well as to monitor and control the quality of the provision of such social services.

The State Standard defines a social service for the social support of families bringing up orphans and children deprived of parental care as a set of measures that provides assistance in creating and maintaining a positive social and psychological climate in the family, adapting the child to new conditions, creating the right conditions to meet the individual needs of each orphan and child deprived of parental care in the development and upbringing, protection of the child's property, housing and other rights, promoting the learning and development of a child, helping to strengthen / rebuild families and socially useful relationships, in creating and providing conditions for the child's priority right to adopt, to prepare the child for leaving the family, including for independent living.

The implementation of the specified State Standard requires quality monitoring through social audit and inspection, including visits to the recipient of social support services at their place of residence (stay), without warning in advance; collecting additional information regarding the recipient of the social support social service; assessing the needs of the recipient of social support social services; drafting, adjusting and amending the social support plan.

Particular attention is paid to the methodological and psychological support of the parents or their substitutes. Thus, the content of social support involves counseling foster parents, caregivers, guardians, carers about their role in overcoming the child's sense of loss; organizing and conducting individual and group work with family members and a child in order to adapt the child to the family living conditions; and if a child has a disability - assistance in obtaining and organizing an individual rehabilitation program, identifying the needs for reasonable accommodation and their ensuarence (means of communication, additional professional services, adaptation of the premises, the choice of presentation format, determination and adherence to the individual regime, etc.); psychological support for foster families, caregivers, guardians, carers for the development and upbringing of children by involving them in trainings, lectures, support groups, and other activities; assistance in protection of property, housing and other rights of a child; redirection of recipients of social services of social support to other providers of social services, including the receipt of specialized services for the full development of a child; counseling recipients of social support services to assist the child in maintaining the continuity of family relationships and socially beneficial relationships; psychological support for recipients of social assistance in creating and securing the right of a child to be adopted; development of skills in preparing a child for independent life; information on the bodies, organizations and institutions that can support a child after leaving family care; keeping records.

The state standard declares the following basic principles of providing social services of social support: accessibility of social service of social support; the independence of the recipient of the social service of social support; its protection and safety; confidentiality of information (Ministry of Social Policy, 2017).

The financial and economic justification grounds on the cost of the social service of social support. It is calculated taking into account its cost, administrative costs and value added tax in accordance with the legislation. The cost of social support services provided through local budgets is based on the financial capacity of the respective local budgets.

Adopted in June 26, 2019 ordinance of the Cabinet of Ministers of Ukraine "Some issues of payment state social assistance for orphans and children deprived of parental care, 
financial support for foster families for providing social services in family type orphanages on a "money go after a child" principle, payment for child patronage services and social support payment to maintain a child in the family of patronate caregiver, small group homes supporting" aimed at social support for orphans and children deprived of parental care (Cabinet of Ministers of Ukraine, 2019).

The aforementioned normative act was developed in accordance with the second paragraph of Article 97 of the Budget Code of Ukraine in order to streamline the mechanism of granting a subsidy from the state budget to local budgets for the payment of state social assistance to specific categories of population.

The resolution adopted by the Cabinet of Ministers of Ukraine (2019) approved the following:

- the procedure and conditions for granting state budget subsidies to local budgets for the payment of state social assistance for orphans and children deprived of parental care, financial support to caregivers to provide social services in orphanages, for foster families by the principle of "money goes after the child", payment for the services of patronage of the child and payment of social assistance for the maintenance of a child in the family of the patronary caregiver, support for small group homes;

- the procedure for the appointment and payment of state social assistance for orphans and children deprived of parental care, financial support for caregivers and foster parents for providing social services in orphanages and foster families on the principle of "money does after the child", support for small group homes. The mentioned Order of Assignment and Payment provides for the removal of the restriction on the total amount of financial support to caregivers and foster parents in order to provide equal financial guarantees to all orphans and children deprived of parental care.

The Ministry of Social Policy of Ukraine is the main manager of the subvention. The structural subdivisions for social protection of the population of the regional state administrations are the managers of the subordinate budget funds; structural subdivisions on social protection of population of district state administrations, executive bodies of city or district councils.

Among the expected results of the implementation of this state document are the increase in the number of children arranged in families with a parallel decrease in the number of families, including children with disabilities, in institutional care establishments; expanding the range of services for children and families with children in the community for the temporary care and upbringing of children in difficult life circumstances, in the families of patronage caregivers and other alternative forms of care and upbringing; creation of financial incentives for the development of care services for children in difficult life circumstances, in the family environment, accelerating the transformation of residential care institutions for children (Cabinet of Ministers of Ukraine, 2019).

\section{Conclusions.}

Therefore, after highlighting and analyzing certain aspects of state policy on social support for orphans and children deprived of parental care, we can distinguish the following innovative features of social protection of children deprived of parental care:

- innovative development of the Ukrainian social support system for orphans and children deprived of parental care, driven by positive world experience and focused on protecting the best interests of a child and meeting his vital needs;

- reforming the social protection system requires active interaction between the state and civil society institutions, aimed at deinstitutionalizing orphaned children and children deprived of parental care, and reorienting the principles of financial support for families with foster children;

- main vectors for social support for orphans and children deprived of parental care mentioned in government documents are the 
modernization of approaches to financing institutions, the approval of co-financing mechanisms from state and local budgets, and the approval of state standards for social care for families with children of this category.

The presented study does not claim to be comprehensive, so it will be promising to study and analyze regional social welfare programs for orphans and children deprived of parental care in the context of decentralization and funding.

\section{References}

Cabinet of Ministers of Ukraine (2019), Resolution of the Cabinet of Ministers of Ukraine "Some issues of payment of state social assistance to orphans and children deprived of parental care, financial support to caregivers and foster parents for providing social services in family-type or foster care homes, payment for services on patronage of a child and payment of social assistance for the maintenance of a child in the family of a patron caregiver, support for small group homes", available at: https://zakon.rada.gov.ua/laws/show/552-2019-\%D0\%BF (Accessed 11 April 2019).

Ministry of Social Policy (2017), Order "On approval of the State standard of social support for families raising orphaned children and children deprived of parental care”, available at: https://zakon.rada.gov.ua/laws/show/z1089-17 (Accessed 11 April 2019).

Ministry of Social Policy (2018), Letter "The purpose of deinstitutionalization is to realize the right of every child to a family", available at: https://www.msp.gov.ua/news/15560.html (Accessed 11 April 2019).

Ministry of Social Policy (2019), "State social standards", available at: https://www.msp.gov.ua/content/socialnistandarti.html (Accessed 11 April 2019).

Mordan, O. O. (2015), "Public policy is about different people who were not caring for people", Abstract of Ph.D. dissertation, National Academy for Public Administration under the President of Ukraine, Kyiv, Ukraine, available at: http://academy.gov.ua/pages/dop/138/files/26f548cf-8ca4-4f76-b1e8-6686bfdb58b3.pdf (Accessed 11 April 2019).

Pohribna, O. S., Shevchenko, T. I. and Yevdokymova, A. V. (2015), "Public administration in the field of social protection of orphans and children deprived of parental care in Sumy region", Visnyk SumDU. Seriia “Ekonomika”, no 4, pp. 72-82.

Polyakova, O. M. (2013), "On the legal socialization of orphans and children deprived of parental care", Pedahohichni nauky: teoriya, istoriya, innovatsiyni tekhnolohiyi, no. 4(30), pp. 376-382.

Potopakhina, O. M. (2008), “Social protection for orphans and children deprived of parental care”, Ph.D. Thesis, Labor Law; Social Security Law, Odesa National Academy of Law, Odesa, Ukraine, available at: http://dspace.onua.edu.ua/handle/11300/1690 (Accessed 11 April 2019).

Prokopenko, O. S. (2018), "Social protection of orphans and children deprived of parental care in Ukraine", International Journal of Innovative Technologies in Social Science, no. 4(8), vol. 2, pp. 9-15. DOI: https://doi.org/10.31435/rsglobal ijitss/01062018/5700 (Accessed 11 April 2019).

The Verkhovna Rada of Ukraine (2015), The Law of Ukraine "On Ensuring Organizational and Legal Conditions for Social Protection of Orphans and Children Deprived of Parental Care”, available at: https://zakon.rada.gov.ua/laws/show/2342-15 (Accessed 11 April 2019).

The Verkhovna Rada of Ukraine (2017a), "National strategy for reforming the institutional care and upbringing of children for 2017-2026", available at: https://zakon.rada.gov.ua/laws/show/526-2017-\%D1\%80 (Accessed 11 April 2019).

The Verkhovna Rada of Ukraine (2017b), "Plan of measures for the implementation of Phase I of the National Strategy for Reforming the Institutional Care and Child Care System for 2017-2026", available at: https://zakon.rada.gov.ua/laws/show/526-2017-\%D1\%80 (Accessed 11 April 2019).

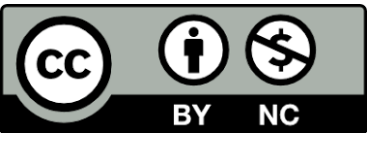

Цей твір ліцензовано на умовах Ліцензії Creative Commons «/з Зазначенням Aвторства - Некомериійна 4.0 Міжнародна» (CC BY-NC 4.0). This is an open access journal and all published articles are licensed under a Creative Commons "Attribution-NonCommercial 4.0 International" (CC BY-NC 4.0). 